sciendo Порівняльна професійна педагогіка 8(3)/2018

Comparative Professional Pedagogy 8(3)/2018

DOI: $10.2478 /$ rpp-2018-0043

Master of Engineering, Lecturer, ADINIFE PATRICK AZODO

Federal University of Agriculture Address: Alabata Rd., Abeokuta, Nigeria

E-mail: azodopat@gmail.com

Professor of Mechanical Engineering (Ergonomics), Lecturer,

SALAMI OLASUNKANMI ISMAILA

Federal University of, Abeokuta, Nigeria

Address: Alabata Rd., Abeokuta, Nigeria

E-mail:ismailasalami@yahoo.com

Professor of Computer Aided Engineering (CAD, CAM, AI, Robotics and

Mechatronics), Lecturer, SAMUEL BABATUNDE ADEJUYIGBE

Federal University of Abeokuta, Nigeria

E-mail: samuel.adejuyigbe@fuoye.edu.ng

\title{
ANALYSIS OF OCCUPATIONAL EXPOSURE INCIDENT AMONG ENGINEERING STUDENTS DURING INDUSTRIAL TRAINING IN NIGERIA
}

\begin{abstract}
Occupational training is a crucial feature in enhancing workforce efficiency and the expertise involved in any profession. This is carried out through a variety of ways such as institutional training, basic instructions, excursions, industrial training, laboratory lessons, workshop operations, field studies, intensive problem-solving based seminars, personal contacts with experts and various "extempore modus operandi" in one's chosen profession, and extracurricular activities. This study analyses the associated occupational exposure incidents of Nigerian engineering students during their 6-month industrial work experience. Data were collected using a pre-tested, self-administered questionnaire having 5-point Likert scale and closed format. The defined conceptual basis and aim of the study guided the questionnaire development. These include employer imposed factors, job/work factors, and trainee (student) factors. The analyzed data showed that the level of occupational exposure incidents observed among Nigerian engineering students in their places of attachment was minimal. However, the observed levels of occupational exposure in this study were a result of uncontrolled hazards which cause occupational diseases among industrial trainees (students). This goes to state that appropriate basic safety practice which is one of the major work ethics in engineering profession should be given utmost consideration by all concerned parties to ensure reduction of hazards in work environment to its barest minimum.

Keywords: exposure, student, training, occupational, engineering, industrial trainee, hazard, Nigeria.

\section{INTRODUCTION}

Engineering education all over the world is based on the fact that practical learning and application of scientific knowledge in engineering are vital. These involve a range of tutelage activities in schools as well as work experience both in formal and informal
\end{abstract}


settings. The paramount nature and act involved in students' work placement oblige active participation of students in particular range of practical tasks or duties other than merely observing other employees or the trainers at their specific tasks (Dodge \& McKeough, 2003; Noor et al., 2015; Fauzi, 2013; Kofli, 2012; Ayarkwa, 2012; Norazah et al., 2012). Active involvement of students to the daily routine and operational activities in the work environment where they are employed for the practical knowledge exposure just like every other employee but with particular emphasis on the learning aspects of the experience is called work experience/placement or industrial training. Industrial training or work-based learning opportunities presume positive effect in career development and preparation of the trainees (Kofli et al., 2012; Mat et al., 2011; Paisey \& Paisey, 2010, Muda, et al., 2010; Omar et al., 2008). Empirical evidence collected by researchers showed that opportunities inherented in industrial training are of mutual benefit to both the establishment offering the training and the trainee (Mat et al., 2011; Paisey \& Paisey, 2010; Muda, et al., 2010; Fallows \& Steven, 2000; Maelah et al., 2012). This implies that it takes a proper and ample commitment of both parties to the training course for effective result to be achieved.

Taking up an occupation or work either as a full-time worker, part-time worker or an industrial trainee within any organization simply implies working under the terms or conditions which that organization imposes (Lowden et al., 2011). It includes human nature, technical nature, and environmental impact risks. Workers and trainees in a workplace are both exposed to the unforeseen and sometimes violent events that arise from work situations which may cause cuts/lacerations, burns, fractures/dislocations, contusion, sprains/strains, loss of limb, eyesight or hearing and, in the extreme, of life itself. The type of mishap the workers are exposed to is a function of the potential hazard present in the work environment (Ergor et al., 2003; Kalejaiye, 2013). Potential hazards due to occupational exposure in the workplace could be without presence of a physical injury. On the other hand, occupational exposure may result in acute, immediate or chronic occupational ailments (Azodo \& Adejuyigbe, 2013), which the observances of necessary safety precautions can reduce to a minimal level.

Safety precautions and observances which necessitates accident-free workplace and effective operations in the work environment especially among trainees (students) seem to have little or no substantiated support in the research literature. Prior studies on students' industrial work experience focused on the positive and negative aspects of occupational proficiency experienced by students during industrial training (Ayob et al., 2013); strengths and weaknesses of industrial training stakeholders in actualizing the aim of the programme and what can be done to improve the system; advantages work placements offer (Bowes \& Harvey, 1999; Mason et al., 2003); importance of work placement in development and enhancement of students' professional skills and employability (Ab Rahman et al., 2009; Kagaari, 2007; Xiao, 2012; Pool \& Sewell, 2007; Harvey, 1999; Davies, 2000; Smith et al., 2009; Alexander et al., 2012; Rodzalan \& Saat, 2012). Occupational training is not limited to having vocational and professional proficiency and competence in handling tasks obtainable in one's profession. Harris et al. (2013) explicitly stated the responsibility of engineers concerning issues affecting health, welfare, and safety of the public. It is vital that acquaintance and compliance with the basic safety practices in different job requirements procedure in engineering profession remain the paramount basis in the engineering students' training (Dodge \& McKeough, 2003; Harris et al., 2013). 
Sciendo Порівняльна професійна педагогіка 8(3)/2018

Comparative Professional Pedagogy 8(3)/2018

\section{THE AIM OF THE STUDY}

With the fore-knowledge of occupational health and safety challenges in Nigeria based companies (Iden, 2010; Okojie, 2010; Idoro, 2011) and the role that the sector plays in enhancing students' occupational training, this study was conducted to examine the associated occupational exposure incidents of Nigerian engineering students during their 6-month industrial work experience period.

\section{THEORETICAL FRAMEWORK AND RESEARCH METHODS}

The problem under research was thoroughly studied by M. Ab Rahman et al. (2009), A. Alexander et al. (2012), J. Ayarkwa et al. (2012), A. Azodo \& S. Adejuyigbe (2013), C. Harris et al. (2013), G. Idoro (2011), P. Kalejaiye (2013), M. Omar et al. (2008) and other scholars.

This cross-sectional study was conducted among engineering students from two selected Federal Universities in Southern (Edo and Ogun states) Nigeria. The population sample for this study comprised final year undergraduate engineering students of five years engineering studies in the country, who have according to the curriculum duly participated in the SIWES programme. Before the study was conducted, it was ensured that the SIWES programme defense has been conducted in all the departments in both schools selected as case studies. The aim and the conceptual basis of the study were explained to the participants whose consent was demonstrated in responding to the questions in the questionnaires. Participation was voluntary. The survey instrument used as data collection tools for this study was a self-administered questionnaire with 5-point Likert-type scaling (ranging from 1 as strongly disagree to 5 as strongly agree) and closed format questions. The questionnaire was designed in reference to the defined conceptual basis and aim of the study. Item selection and adaptation for the study was compiled after a broad-based consultation of the related literature. The defined conceptual basis for the development of this questionnaire was based on the following; employer imposed factors: job/work factors, and trainee (student) factors. These were extensively classified and assessed as availability, provision and usage of the personal protection equipment (PPE), machine/equipment condition in the place of industrial training, hazard exposure, injury, characteristics of the injuries and reasons for the incidents. Students filled out the questionnaire individually with the administrator.

The suitability of using the items selected for this study was ascertained by industrial safety and ergonomics experts, through a series of item modifications and adjustments for the theoretical content, suitability and questionnaire functionality. Afterward, the questionnaire was pre-tested for reliability few weeks to the data collection with a sample of fifteen engineering students randomly chosen from one of the schools selected as proposed study population with an equal distribution sample of three questionnaires for each of the engineering departments in the school. The Cronbach's alpha computed to ascertain internal consistency of the data collection tool gave an output of 0.87 . The interpretation of the Cronbach's alpha computation according to the rule of thumb by George and Mallery (2003) (>0 0.9 (Excellent), > 0.8 (Good), > 0.7 (Acceptable), $>0.6$ (Questionable), $>0.5$ (Poor), and $<0.5$ (Unacceptable)) is an indication that the research tool has good reliability. The data obtained were analyzed and tabulated using the Statistical Package for the Social Sciences (SPSS) 16.0.

\section{RESULTS}

Demographic characteristics of respondents. The sample population interviewed using the designed questionnaire comprises one hundred and thirty-one engineering students, the majority of which were males $(90.1 \%)$. The age range of the study participants covers from 19 to 30 years, with mean age value of 23.74 years. The marital status distribution was single $(96.9 \%)$ and married $(3.1 \%)$. 
Occupational exposure circumstances and conditions at the places of industrial attachment. The analysis of data showed that (use PPE during SIWES) $44.3 \%$ of the participants never complied to safety measures throughout their period of attachment, 16.3 $\%$ rarely did, $19.1 \%$ and $10.7 \%$ sometimes and often did respectively. It was only $9.2 \%$ of the participants that always complied to them. Safety gadgets provided in some establishments were not up to standard and the PPE were shared among the workers and trainees in some places. Enlightenment concerning hazards associated with each operation involved in the use of machines was an observed condition that leads to occupational exposures among the students in the places of attachment. Ensuring that exposed or protruding parts of machines and equipment are covered during operation, good maintenance culture and discard of old and dilapidated machines are necessary for achieving safety in working environment. The analyzed data also showed that $9(6.7 \%)$ and $20(15.3 \%)$ of respondents strongly agree and agree respectively that in their places of industrial training, machines were old and equipment poorly maintained. This agreed with B. Bolaji and S. Adejuyigbe (2012) that poor maintenance is a challenge in Nigerian industries, thus resulting in a frequent breakdown of the production machines. There is the tendency of poorly maintained equipment or machine to malfunction and cause accident thereby exposing workers to unnecessary hazards. Good maintenance culture is imperative to the working life and necessary to keep the workers, equipment, and machines in proper and safe operating conditions (Khurmi \& Gupta, 2010).

Students undertaking their industrial training in any establishment are expected to work according to the rules and agreement terms of the place where they are employed for their industrial training (Adeogun \& Okafor, 2013). Likewise, it is expected that the human nature, technical nature and environmental impact risks prevailing in the establishment should be in compliance with the operational standard for the programme to thrive. The vast involvement of different establishments that fundamentally deal with engineering projects provides inestimable work exposure to the students (Ayob et al., 2013). According to J. Garrick et al. (2004), hands-on experience prevalent in industrial training makes learning experience and knowledge more appreciative due to the creative and innovative approaches utilized in problem-solving. Hands-on exposure or real-world confrontation furnishes the students with an overall of on-the-job experience and career exposure in the engineering profession. However, contrary experiences do happen in the course of students' training experience (Ayob et al., 2013). The challenges and exposure in engineering work environment are more complex and extensive compared to school environment. Every engineering work environment contains some potential hazards. The potential hazards in work environment often present themselves in workers' or personnel injury, loss of production and damage to machines, tools, and equipment. All the same, these hazards could be avoided through proper safety observances (Khurmi \& Gupta, 2010). The type of personal protective equipment used in a place of work is pertinent to the category of work and nature of exposure involved. Being safely ready is always advisable before entering the job site.

Occupational health and safety challenge is a long-standing issue in Nigeria. Research findings (Iden, 2010 and Okojie, 2010) showed that a few companies such as big multinationals who run the policies constituted in their countries of origin are the only organizations that recognize occupational health and safety in Nigeria. G. Idoro (2011) added that there are no reflections of contractors' management efforts in Nigeria on occupational health and safety in their scope of operations which results in high accident and injury rates 
sciendo Порівняльна професійна педагогіка 8(3)/2018 Comparative Professional Pedagogy 8(3)/2018

witnessed in the Nigerian construction industry. Weaknesses and ineffective management of occupational health and safety is a gross challenge, in spite of the existence of system responsible for ensuring health and safety in the nation (Adeogun \& Okafor, 2013). Literature revealed that occupational accidents are relatively higher among young workers within the age limit of 15-24 years (Damen, 2013). The observation in this study was found to be in line with M. Damen et al. (2013) as the mean age of the participants in this study falls within the same range. The occupational exposure factors observed in this study include inadequate training and supervision, inexperience, lack of awareness, the pressure to work fast and carelessness (Table 1).

Table 1

Conditions leading to occupational exposures

\begin{tabular}{|l|c|c|c|c|c|}
\hline \multicolumn{1}{|c|}{ Characteristics } & $\begin{array}{c}\text { Strongly } \\
\text { agree }\end{array}$ & Agree & Undecided & Disagree & $\begin{array}{c}\text { Strongly } \\
\text { disagree }\end{array}$ \\
\hline $\begin{array}{l}\text { Poor/No enlightenment } \\
\text { of hazards associated with } \\
\text { each operation by my employer }\end{array}$ & $2(1.5)$ & $15(11.5)$ & $13(9.9)$ & $57(43.5)$ & $44(33.6)$ \\
\hline $\begin{array}{l}\text { Poor communication/ } \\
\text { relation in the place } \\
\text { of attachment }\end{array}$ & $64(48.9)$ & $43(32.8)$ & $12(9.2)$ & $9(6.9)$ & $3(2.3)$ \\
\hline Unsafe equipment & $5(3.8)$ & $17(13.0)$ & $6(4.6)$ & $20(15.3)$ & $78(59.5)$ \\
\hline $\begin{array}{l}\text { Old and poorly maintained } \\
\text { equipment }\end{array}$ & $9(6.9)$ & $20(15.3)$ & $26(19.8)$ & $44(33.6)$ & $31(23.7)$ \\
\hline $\begin{array}{l}\text { Inadequate training } \\
\text { and supervision }\end{array}$ & $3(2.3)$ & $16(12.2)$ & $13(9.9)$ & $25(19.1)$ & $70(53.4)$ \\
\hline Inexperience & $13(9.9)$ & $26(19.8)$ & $13(9.9)$ & $14(10.7)$ & $58(44.3)$ \\
\hline Lack of awareness & $5(3.8)$ & $21(16.0)$ & $16(12.2)$ & $22(16.8)$ & $60(45.8)$ \\
\hline Pressure to work faster & $5(3.8)$ & $25(19.1)$ & $12(9.2)$ & $21(16.0)$ & $61(46.6)$ \\
\hline Carelessness & $10(7.6)$ & $14(10.7)$ & $12(9.2)$ & $25(19.1)$ & $61(46.6)$ \\
\hline
\end{tabular}

This also complies with documentation of EASHW, 2009 which expatiated widely on the variety of age-related factors such as lack of experience, skills, training, risk awareness, knowledge, maturity and speaking out.

Nature of student occupational exposures. The prevailing nature of exposures witnessed among the students includes sprain/ strain, burn, fracture, contusion, temporal hearing loss, cuts, eye defect, musculoskeletal disorder and electric shock (Table 2). It will be agreed from the result obtained in this study that circumstances and conditions leading to these occupational exposures in the places of attachment, explained above, are majorly human factors owing to non-compliance with safety rules. This agrees with A. Kumar and P. Sinha (2008) that human error plays a major role, if not all, in most accidents witnessed in work environment. The study (Kumar \& Sinha, 2008) lists various phases in which human factor manifests in occupational incidents, e. g. system specification, development, and operation. This implies that proper evaluation of various risks involved in job specifications in the workshop, and appropriate implementation and adherence to the safety rules by all the stakeholders is a determining factor in achieving absolute safety in the work environment (Azodo, \& Adejuyigbe, 2013). 
sciendo Порівняльна професійна педагогіка 8(3)/2018 Comparative Professional Pedagogy 8(3)/2018

Table 2

Characteristics of student occupational exposures

\begin{tabular}{|l|c|c|c|c|c|}
\hline \multicolumn{1}{|c|}{ Characteristics } & $\begin{array}{c}\text { Strongly } \\
\text { agree }\end{array}$ & Agree & Undecided & Disagree & $\begin{array}{c}\text { Strongly } \\
\text { disagree }\end{array}$ \\
\hline Sprain/strain & $12(9.2)$ & $27(20.6)$ & $10(7.6)$ & $29(22.1)$ & $51(38.9)$ \\
\hline Burn & $3(2.3)$ & $7(5.3)$ & $10(7.6)$ & $32(24.4)$ & $76(58.0)$ \\
\hline Fracture/dislocation & $8(6.1)$ & $9(6.9)$ & $4(3.1)$ & $34(26.0)$ & $74(56.5)$ \\
\hline Contusion & $7(5.3)$ & $28(21.4)$ & $5(3.8)$ & $28(21.4)$ & $61(46.6)$ \\
\hline Temporal hearing loss & $1(0.8)$ & $5(3.8)$ & $12(9.2)$ & $30(22.9)$ & $77(58.8)$ \\
\hline Cuts & $12(9.2)$ & $31(23.7)$ & $3(2.3)$ & $24(18.3)$ & $59(45.0)$ \\
\hline Eye defect & $9(6.9)$ & $16(12.2)$ & $4(3.1)$ & $25(19.1)$ & $75(57.3)$ \\
\hline Musculoskeletal disorder & $5(3.8)$ & $5(3.8)$ & $5(3.8)$ & $32(24.4)$ & $81(61.8)$ \\
\hline Electric shock & $2(1.5)$ & $11(8.4)$ & $4(3.1)$ & $28(21.4)$ & $84(64.1)$ \\
\hline
\end{tabular}

\section{CONCLUSIONS}

The skills and knowledge engineering students require to fulfill the future requirement as professionals in different areas of expertise depend on what they have been exposed to today. Industrial training gives students an in-depth development in an engineering career and much needed professional engineering identity. If students are not properly trained in terms of professional ethics, skills and knowledge, safety observances, etc., there will appear a deficit of engineering profession in solving problems. Establishments where students had their industrial training expose some unsafe practices and operations, which resulted in occupational exposure among students. It is therefore essential that drastic steps should be taken to ensure strict adherence to work and safety rules in students' work placement.

This study therefore suggests further studies on assessment of work-related hazard identification, probability analysis, deterministic approach in estimation of consequences for various hazards and risk analysis in the diverse engineering courses and disciplines for more effective occupational training of industrial trainees.

\section{REFERENCES}

1. Ab Rahman, M. Z., Omar, M. Z., Kofli, N. T., Mat, K., Osman, S. A., \& Darus, Z. (2009). Assessment of Engineering Students Perception after Industrial Training Placement. European Journal of Social Sciences, 8 (3), 420-431.

2. Adeogun, B. K., \& Okafor, C. C. (2013). Occupational health, safety and environment (HSE) trend in Nigeria. International Journal of Environmental Science, Management \& Engineering Research, 2 (1), 24-29.

3. Alexander, A., William, A. A., Asaah, J. A., \& Zakari, A. (2012). The impact of students' industrial training on their employability status after graduation: evidence from Kumasi in Ghana. International Journal of Advances in Management \& Economics, 1 (4), $108-114$

4. Ayarkwa, J., Adinyira, E., \& Osei-Asibey, D. (2012). Industrial training of construction students: perceptions of training organizations in Ghana. Education+ Training, 54 (2 \& 3), 234-249.

5. Ayob, A., Osman, S. A., Omar, M. Z., Jamaluddin, N., Kofli, N. T., \& Johar, S. (2013). Industrial training as gateway to engineering career: experience sharing. Procedia-Social \& Behavioral Sciences, 102, 48-54. 
sciendo Порівняльна професійна педагогіка 8(3)/2018

Comparative Professional Pedagogy 8(3)/2018

6. Azodo, A. P., \& Adejuyigbe, S. B. (2013). Nigerian engineering students' compliance with workshop safety measures. International Journal of Innovation \& Applied Studies, 3 (2), 425-432.

7. Bolaji, B. O., \& Adejuyigbe, S. B. (2012). Evaluation of maintenance culture in manufacturing industries in Akure metropolitan of Nigeria. Journal of Information Engineering \& Applications, 2 (3), 37-44.

8. Bowes, L., \& Harvey, L. (1999). The Impact of Sandwich Education on the Activities of Graduates Six Months Post Graduation. Birmingham: University of Central England in Birmingham, Centre for Research into Quality.

9. Damen, M., Berkhout, P., \& Wouters, R. (2013). Risks to young people at work: experience or exposure? Safety Science Monitor, 17 (1).

10. Davies, L. (2000). Why kick the "L" out of "Learning"? The development of students' employability skills through part-time working. Education + Training, 42 (8), 436-445.

11. Dodge, R. B., \& McKeough, M. (2003). Internship and the Nova Scotia Government experience. Education + Training, 45 (1), 45-55.

12. EASHW (2009). Preventing Risks to Young Workers: Policy, Programmes and Workplace Practices. European Agency for Safety and Health at Work.

13. Ergor, O. A., Demiral, Y., \& Piyal, Y. B. (2003). A significant outcome of work life: occupational accidents in a developing country Turkey. Journal of Occupational Health, 45, 74-80.

14. Fallows, S. J., \& Steven, C. (Eds.) (2000). Integrating key skills in higher education: Employability, transferable skills and learning for life. Psychology Press.

15. Fauzi, S. N., Abidin, F. M., \& Awang, H. (2013). Improving graduates' employability skills through industrial training: suggestions from employers. Journal of Education and Practice, 4 (4), 23-29.

16. Garrick, J., Chan, A., \& Lai, J. (2004). University-industry partnerships: implications for industrial training, opportunities for new knowledge. Journal of European Industrial Training, 28 (2, 3, 4), 329-338.

17. George, D., \& Mallery, P. (2003). SPSS for Windows Step by Step: A Sample Guide and Reference, 11.0 Update (4th Ed). Boston, MA: Allyn and Bacon.

18. Harris, Jr C., Pritchard, M., Rabins, M. J., James, R., \& Englehardt, E. (2013). Engineering ethics concepts and cases. 5th ed. Wadsworth Cengage Learning, Boston: United State of America.

19. Harvey, L. (1999). Employability: Developing the relationship between higher education and employment. Quality in Higher Education, 1-14.

20. Iden, E. (2010). Occupational Health and Safety Managers (Nigeria), A Copy of My Appeal Letter to ILO.

21. Idoro, G. I. (2011). Company occupational health and safety (OHS) management efforts and performance of Nigeria construction contractors. Journal of Construction in Developing Countries, 16 (2), 151-173.

22. Kagaari, J. R. (2007). Evaluation of the Effects of Vocational Choice and Practical Training on Students' Employability. Journal of European Industrial Training, 31 (6), 449-471.

23. Kalejaiye, P. O. (2013). Occupational health and safety: issues, challenges and compensation in Nigeria. Peak Journal of Public health \& Management, 1 (2), 16-23.

24. Khurmi, R. S., \& Gupta, J. K. (2010). A textbook of workshop technology (manufacturing processes). Delhi: S. Chand and Company Limited New Delhi. 
sciendo Порівняльна професійна педагогіка 8(3)/2018 Comparative Professional Pedagogy 8(3)/2018

25. Kofli, N. T., Badar, S. N., \& Abdullah, S. R. S. (2012). Trends on industrial placements of students from department of chemical and process engineering. ProcediaSocial and Behavioral Sciences, 60, 308-312.

26. Kumar, A., \& Sinha, P. K. (2008). Human error control in railways. Jordan Journal of Mechanical and Industrial Engineering, 2 (4),183-190.

27. Lowden, K., Hall, S., Elliot, D., \& Lewin, J. (2011). Employers' perceptions of the employability skills of new graduates. University of Glasgow: SCRE Centre and Edge Foundation.

28. Maelah, R., Aman, A., Mohamed, Z. M., \& Ramli, R. (2012). Enhancing soft skills of accounting undergraduates through industrial training. Procedia-Social \& Behavioral Sciences, 59, 541-549.

29. Mason, G., Williams, G., Cranmer, S., \& Guile, D. (2003). How much higher education does enhance the employability of graduates? Report to HEFCE.

30. Mat, K., Omar, M. Z., Osman, S. A., Kofli, N. T., Rahman, M. N. A., Jamil, M., \& Jamaluddin, N. (2011). The Effectiveness of industrial training on UKM Engineering Students. Procedia-Social and Behavioral Sciences, 18, 656-665.

31. Muda, N., Din, U. K. S., Majid, N., Ahmad, R. R., Shahabudin, F. A. A., Rambely, A. S., \& Suradi, N. R. M. (2012). Industrial training as a benchmark of the employability for the mathematical sciences students of UKM. Procedia-Social and Behavioral Sciences, 59, 598-603.

32. Noor, A. J., Lannie, F., Rudy, T., \& Jamil, M. (2015). Competency of civil engineering students undergone industrial training: supervisors' perspectives. ProcediaSocial and Behavioral Sciences, 167, 245-249.

33. Norazah, Y., Muhalim, M. A., Marina, A., Halina, M. D., \& Noorfa, M. (2012). Authentic assessment of industrial training program: experience of universiti teknologi Malaysia. Procedia-Social and Behavioral Sciences, 56, 724-729.

34. Okojie, O. (2010). Systems for reporting occupational diseases in Nigeria, Africa. Newsletter on Occupational Health and Safety, 20 (3), 51-53.

35. Omar, M. Z., Rahman, M. N. A., Kofli, N. T., Mat, K., Darus, Z. M., \& Osman, S. A. (2008). Assessment of engineering students' perception after industrial training placement. 4th WSEAS/IASME, International Conference on educational technologies.

36. Paisey, C., \& Paisey, N. J. (2010). Developing skills via work placements in accounting: student and employer views. Accounting Forum, 34 (2), 89-108.

37. Pool, L. D., \& Sewell, P. (2007). The key to employability: developing a practical model of graduate employability. Education+Training, 49 (4), 277-289.

38. Rodzalan, S. A., \& Saat, M. M. (2012). The effects of industrial training on students' generic skills development. Procedia-Social \& Behavioral Sciences, 56, 357-368.

39. Smith, M., Brooks, S., Lichtenberg, A., McIlveen, P., Torjul, P., \& Tyler, J. (2009). Career development learning: maximizing the contribution of work-integrated learning to the student experience: Australian Learning \& Teaching Council Final project report. University of Wollongong, Careers Central, Academic Services Division.

40. Usman, M. E. (1998). The principle of maintenance culture in a small scale industry: a case of Norchem, Bida, Nigeria. National Engineering Conference Series, 5, 63-66. 